\title{
PИHKOBI ДОСАІДЖЕННЯ
}

УДК 339.13:691.542～DOI: https://doi.org/10.31617/tr.knute.2020(33)02

Valentyna POLUHA PhD (Ing.), Assistant, Department of Commodity Science and Customs Affairs,

E-mail:v.demchenko@knute.edu.ua ORCID: 0000-0001-7527-2236

Kyiv National University of Trade and Economics 19, Kyoto str., Kyiv, 02156, Ukraine

Oksana ZOLOTAROVA E-mail: o.zolotarova@knute.edu.ua ORCID: 0000-0003-2534-3125

$\mathrm{PhD}$ (Ing.), Associate Professor, Department of Commodity Science and Customs Affairs, Kyiv National University of Trade and Economics 19, Kyoto str., Kyiv, 02156, Ukraine

Olga KOMAKHA $\mathrm{PhD}$ (Ing.), Associate Professor, Department of Commodity Science and Customs Affairs,

E-mail: o.s.komakha@knute.edu.ua Kyiv National University of Trade and Economics ORCID: 0000-0003-0312-890X 19, Kyoto str., Kyiv, 02156, Ukraine

\section{CEMENT DRY BUILDING MIXTURES IN UKRAINE: MARKET RESEARCH}

The volume of production and export-import operations of cement dry mixtures in Ukraine is analyzed. The largest countries import-export counter-parties of Ukraine are established. It is revised the structure of cement dry building mixtures market by manufacturers, the dynamics of their prices is analyzed. The main tendencies and perspectives of the cement dry building mixtures market development in Ukraine are determined.

Keywords: cement dry building mixtures, production status, import, export, market.

Полюга В., Золотарева О., Комаха О. Цементные сухие строительные смеси в Украине: рыночные исследования. Проведен анализ объемов производства и экспортно-импортных операций цементных сухих строительных смесей в Украине. Определены крупнейшие страны-контрагенты импорта и экспорта. Рассмотрена структура рынка иементных сухих строительных смесей по производителям. Проанализирована динамика иен на них, определены основные тенденции и перспективы развития рынка цементных сухих строительных смесей в Украине.

Ключевые слова: цементные сухие строительные смеси, состояние производства, импорт, экспорт, рынок.

(C) Valentyna Poluha, Oksana Zolotarova, Olga Komakha, 2020 
Background. The dynamics of the dry building mixtures (DBM) market is closely linked to the development of the construction industry in Ukraine. The building materials industry includes the production of cement, bricks and other masonry materials, concrete and concrete structures, dry mixtures, ceramic tiles, thermal insulation, roofing materials, etc. [1].

The development of the production complex of dry building mixtures is of particular interest. This type of construction materials appeared in Ukraine in the early 2000s. Over the 18 years, the industry has undergone significant changes, indicating the dynamic nature of its development, as evidenced by the location of foreign production in Ukraine, trade in imported materials and rapid development of domestic production of cement DBM.

Analysis of recent research and publications. Trends in the market development and production of DBM, including cement, were reflected in the studies of ukrainian scientists: V. Boreyko [2], Ju. Soha [3], M. Pichugina [4], T. Andreeva [ 5], V. Biba [6]. The basic trends of the development of building materials for the period from 2011 to 2014 have been defined, the basic aspects of pricing and perspectives of building materials production in Ukraine have been given in their scientific works. For example, M. Pichugina examined the state of the building materials market in Ukraine [4]. In [6], a rapid analysis of the construction industry state in the period 2003-2013 was carried out.

It appears important to analyze the situation and identify the main trends in the development of cement DBM production in Ukraine, using the experience of above mentioned researchers.

The aim of the article is to analyze the volumes of production, consumption, import and export of cement DBM in Ukraine in the period from 2011 to 2018.

Materials and methods. General and special methods of analysis and synthesis, systematic approach, scientific generalization and comparison of data of scientific sources (monographs, articles of domestic and foreign scientists), as well as open sources of statistical information according to the State Statistics Service of Ukraine and the State Fiscal Service of Ukraine were used. The volume of export - import operations with dry building mixtures was also analyzed on the basis of the Ukrainian Classification of Goods in Foreign Economic Activity (UCG FEA).

Results. Cement DBMs have been widely used in construction and are used for almost all types of work - both in new construction and during the reconstruction and repair of buildings. Construction technology using such DBMs can significantly improve the quality and reduce the material consumption of construction work. The main advantage of the above mentioned DBMs is that the cement provides the maximum strength of fixation of the material [7], but the other advantages are also important:

- multicomponent composition that needs only the addition of water to be ready to use, which significantly saves time to prepare the mix;

- quality control of components, so manufacturers of cement-based DBM use only high quality components;

- high degree of adhesion of the mixture to the base;

- ease of use. 
The disadvantages of these products include the high price of such mixtures produced by the consumer himself.

Cement DBM can be used in a wide variety of construction works from masonry to finishing [8]. The dynamics of cement SBS production during 2011-2018 is presented in Figure 1.

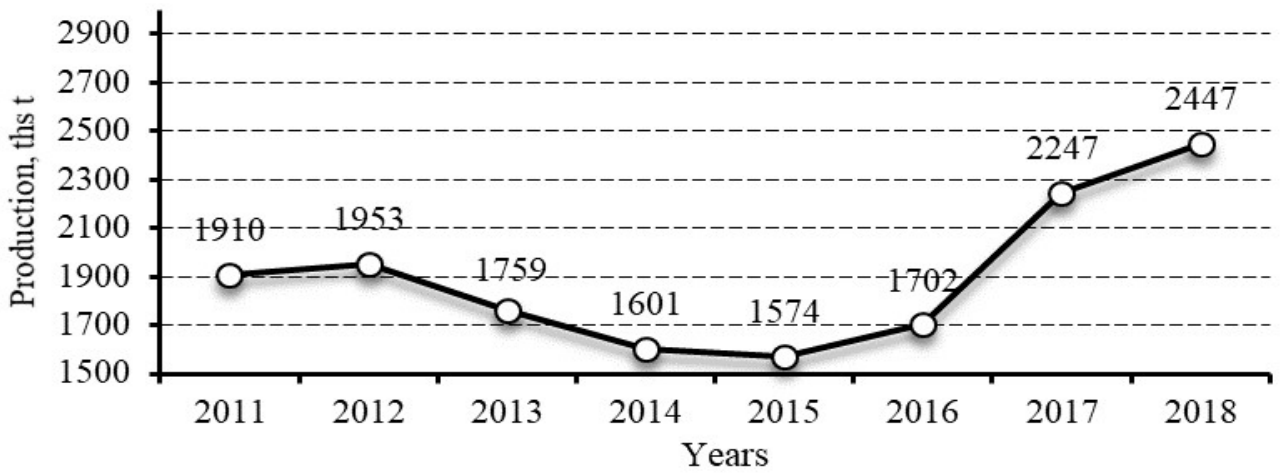

Figure 1. Production of cement DBM in Ukraine during 2011-2018 Source: developed by the authors according to [9].

There has been an ambiguous situation in the cement DBM market in recent years according to the State Statistics Service of Ukraine. The production volumes decreased by $17.6 \%$ in the period from 2011 to 2015 , this indicator increased by $35.6 \%$ starting from 2015 till 2018 [9].

The leading position in the structure of DBM production (by the composition of binders) is taken by binders with portland cement $(57 \%)$, second - with gypsum (21\%) and the third rate belongs to the lime-based DBMs $(14 \%)$ [9].

Cement DBM consumption in Ukraine fluctuates depending on the year. The decrease in the period $2013-2015$ by $10.5 \%$ was shown due to the relatively higher cost of raw production materials for this type of goods in comparison with others. However, during 2015-2018, there was a constant tendency to increase consumption of cement-based DBM - by $41.5 \%$ at the end of the period (Figure 2). Analysis of the production and consumption of cement-based DBM in Ukraine indicates that this product is of high demand among domestic consumers [9].

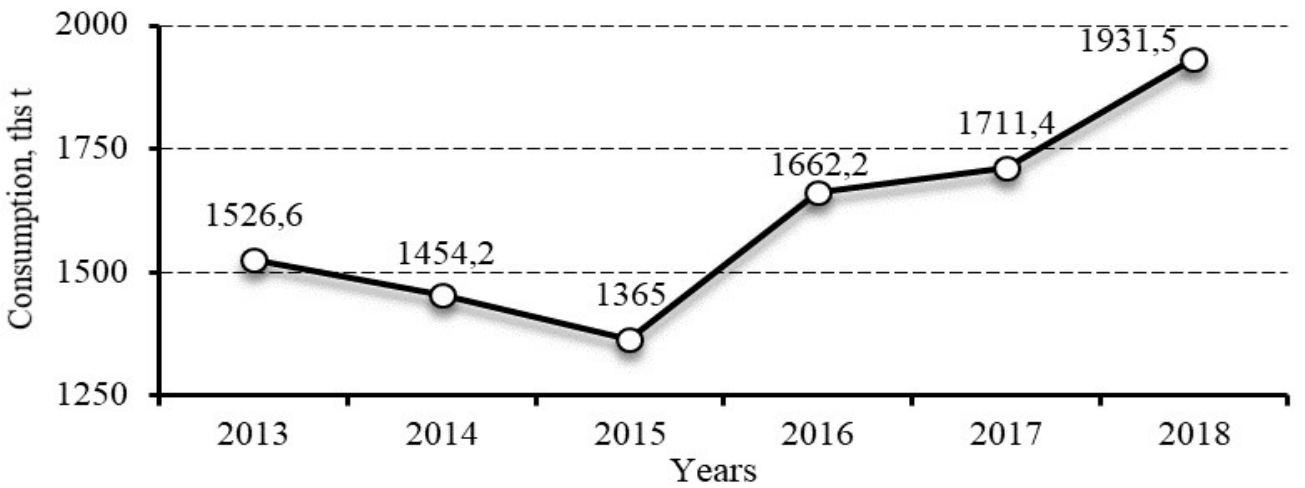

Figure 2. Consumption volumes of cement DBM in Ukraine in the period 2013-2018 Source: developed by the authors according to [9]. 
Today there are almost 100 manufacturers of cement DBM in Ukraine, but $75-80 \%$ of production are comprised by main 4 companies: Henkel Bautechnik (Ukraine) LLC (Vyshgorod), Fomalgaut-POLIMIN LLC. Polirem LLC (Kyiv) and Helios LLC (Lviv) [10].

ABC, STABILL, SCANMIX, KNAUF, CERESIT, EKOGIPS, EUROGIPS and ARTISAN are among the global brands that present their cement DBM on the Ukrainian market. However, domestic producers gained about $70 \%$ of the Ukrainian market within a few last years (Table 1).

Table 1

The main manufacturers of cement DBM in Ukraine in 2018

\begin{tabular}{l|c|c}
\hline \multicolumn{1}{c|}{ Manufacturer } & Trademark & $\begin{array}{c}\text { Production volume, } \\
\text { ths } \mathrm{t}\end{array}$ \\
\hline Henkel Bautechnik (Ukraine) LLC & $\begin{array}{c}\text { CERESIT, } \\
\text { MOMEHT }\end{array}$ & 525 \\
\hline Knauf Gypsum Donbass LLC & KNAUF & 430 \\
\hline IPG MASTER LLC & MASTER & 165 \\
\hline LLC "Fomalhaut-POLYMIN" & POLIMIN & 240 \\
\hline PJSC "Terminal-M" & SILTEK & 120 \\
\hline ASCONA-PIVDEN LLC & ANSERGLOB & 160 \\
\hline LLC "Building mixtures factory" Budmaster " & BUDMAISTER & 120 \\
\hline LLC "Chrysel - Building Materials" & KREISEL & 90 \\
\hline Baumit Ukraine LLC & BAUMIT & 120 \\
\hline Ferozit LLC & FEROSIT & 100 \\
\hline LLC Polirem & POLIREM & 110 \\
\hline Others & - & 267 \\
\hline TOTAL & & 2447 \\
\hline
\end{tabular}

Source: [10].

Prices monitoring on the cement DBM market has shown the constant growth of prices for cement DBM regardless of their types (Figure 3).

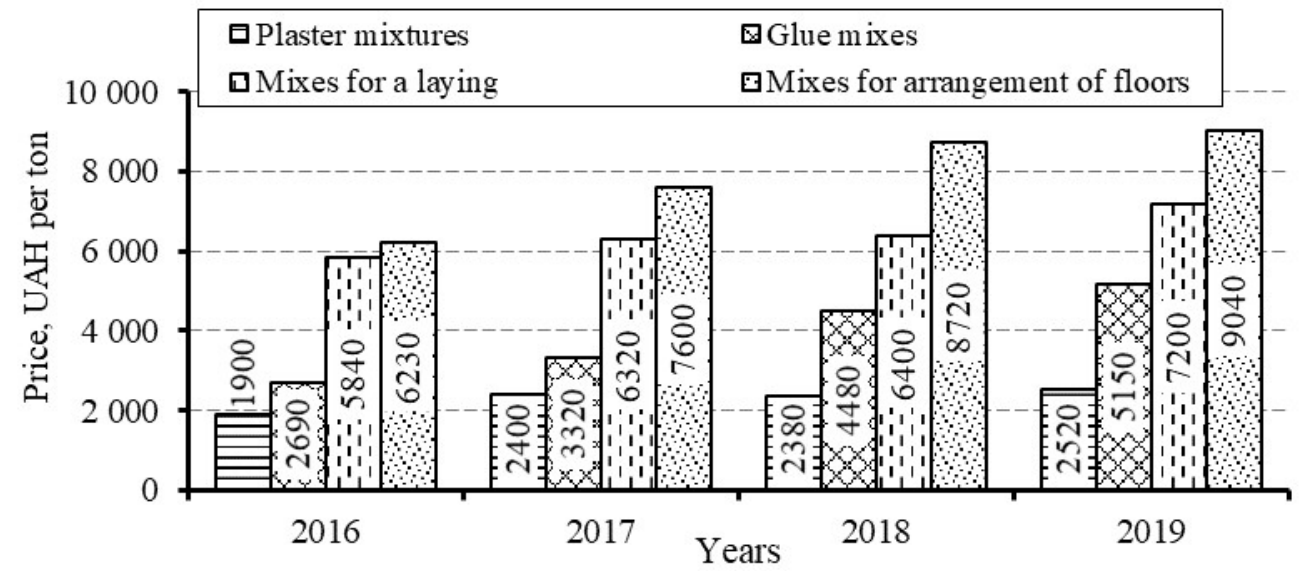

Figure 3. Price dynamics for cement DBM in Ukraine in the period 2016-2019 Source: developed by the authors according to [11]. 
The data (see Fig. 3) showed that cement mixtures for flooring retain the highest price with an increase of $40 \%$ in three years, prices for masonry mixtures increased by $23 \%$ and plaster mixes - by $32 \%$. A similar tendency is typical for adhesive mixtures used for tile laying. The price for this product increased by almost 2 times in the period from 2011 to 2019. The trends of sharp price rise for the above-mentioned cement DBMs can be caused by the increase of raw material prices, as well as the use in the production of mixtures of foreign origin raw materials, which are much more expensive than domestic analogues [11].

The dynamics of foreign trade operations with cement DBM was analyzed for the period from 2015 for the goods classified under commodity subheading 382450 of UCG FEA based on the data of the State Statistics Service of Ukraine (Figure 4) [12].

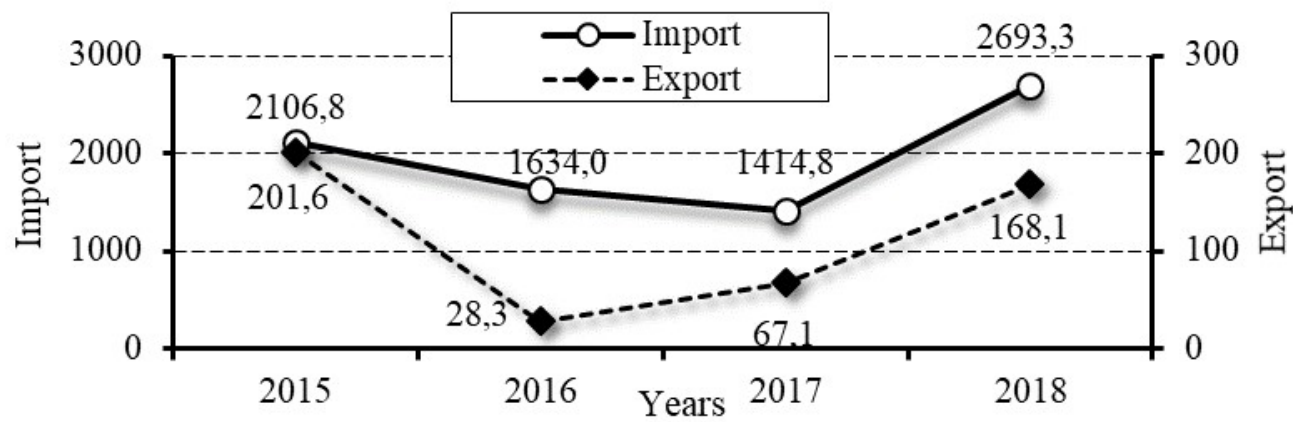

Figure 4. Volume of import and export of cement DBM in Ukraine in the period 2015-2018, ths USD

Source: developed by the authors according to [12].

According to the State Statistics Service of Ukraine, the volume of the cement-based DBMs import decreased by almost $30 \%$ in the period from 2015 till 2017 and showed 2 times increase from 2017 till 2018.

If to analyze the export of cement-based DBMs from Ukraine to foreign countries, its volume reduced by almost $17 \%$ in the period from 2015 till 2018 [12].

In foreign trade the cement DBMs are classified in the heading 3824500000 of UCG FEA "Non-refractory mortars and concretes". In 2018, the leader of non-refractory mortars and concrete import to Ukraine (including cement DBMs) in value terms was Italy, second place hold Germany and the next one was Turkey. At the same time, Italy's share in the general structure of the non-refractory mortars and concrete import to Ukraine (incl. cement DBMs) was $49 \%$, Germany - $13 \%$, Turkey - $9 \%$. Austria, Slovakia and the Netherlands had the smallest shares (Table 2).

Regarding the volume of non-refractory mortars and concrete export from Ukraine (incl. cement DBMs), domestic manufacturers mostly exported them to Poland, Latvia and Georgia. In 2018 Poland's share in the total export structure was $79 \%$, Latvia had $9 \%$, Georgia $-8 \%$. 
Exports and imports of non-refractory mortars and concrete (including cement DBMs) to Ukraine in 2018

\begin{tabular}{|c|c|c|c|c|}
\hline \multirow[b]{2}{*}{ Country } & \multicolumn{2}{|c|}{ Export } & \multicolumn{2}{|c|}{ Import } \\
\hline & $\begin{array}{l}\text { Quantity, } \\
\text { kg }\end{array}$ & $\begin{array}{l}\text { Value, } \\
\text { ths USD }\end{array}$ & $\begin{array}{l}\text { Quantity, } \\
\text { kg }\end{array}$ & $\begin{array}{l}\text { Value, } \\
\text { ths USD }\end{array}$ \\
\hline TOTAL & 1638110.6 & 168.1 & 3361409.1 & 2693.3 \\
\hline I. CIS COUNTRIES & 25730.1 & 2.4 & 345611.4 & 141.1 \\
\hline Belarus & 80.1 & 0.8 & 17875.0 & 11.3 \\
\hline Republic of Moldova & 25650.0 & 1.5 & - & - \\
\hline Russian Federation & - & - & 327736.4 & 129.8 \\
\hline $\begin{array}{l}\text { II. OTHER COUNTRIES } \\
\text { OF THE WORLD }\end{array}$ & 1612380.6 & 165.7 & 3015797.7 & 2552.2 \\
\hline Europe, in particular & 1608321.6 & 151.5 & 2004035.3 & 2286.6 \\
\hline Austria & - & - & 970.0 & 0.7 \\
\hline Belgium & - & - & 129650.0 & 166.0 \\
\hline Greece & - & - & 74656.0 & 51.5 \\
\hline Denmark & - & - & 77450.0 & 35.9 \\
\hline Estonia & - & - & 7.5 & 0.0 \\
\hline Spain & - & - & 13267.0 & 69.6 \\
\hline Italy & - & - & 683445.0 & 1310.0 \\
\hline Latvia & 54000.0 & 15.4 & 4337.0 & 125.5 \\
\hline The Netherlands & - & - & 1195.9 & 2.3 \\
\hline Germany & - & - & 430472.4 & 354.1 \\
\hline Poland & 1551600.0 & 133.2 & 441908.8 & 126.3 \\
\hline Serbia & - & - & 21600.0 & 5.7 \\
\hline Slovakia & - & - & 1800.0 & 0.3 \\
\hline Hungary & - & - & 86575.7 & 13.8 \\
\hline Czech Republic & 2721.6 & 3.0 & 36700.0 & 25.0 \\
\hline Asia, in particular & 4059.0 & 14.2 & 995809.4 & 249.7 \\
\hline Georgia & 4059.0 & 14.2 & - & - \\
\hline Turkey & - & - & 995809.4 & 249.7 \\
\hline America, in particular & - & - & 15953.0 & 15.9 \\
\hline USA & - & - & 15953.0 & 15.9 \\
\hline
\end{tabular}

Source: developed by the authors according to [13].

According to the State Statistics Service of Ukraine, Germany and Italy were the leaders of non-refractory mortars and concrete import to Ukraine (incl. cement DBMs) in the period 2015-2019 (Figure 5).

In the period 2015-2019, the share of Italian non-refractory mortars and concrete (including cement DBMs) in the import structure of Ukraine decreased by almost 13 times. Germany's share in the import in 2019 compared to 2015 increased more than 4 times. In 2019 the US share was $18.69 \%$, which is almost 3 times higher than in 2015. Poland and Hungary had the smallest share in the import structure of non-refractory mortars and concrete (including cement DBMs) to Ukraine during 2015-2019. In 2019 their shares were $9.93 \%$ and $1.73 \%$, respectively. 


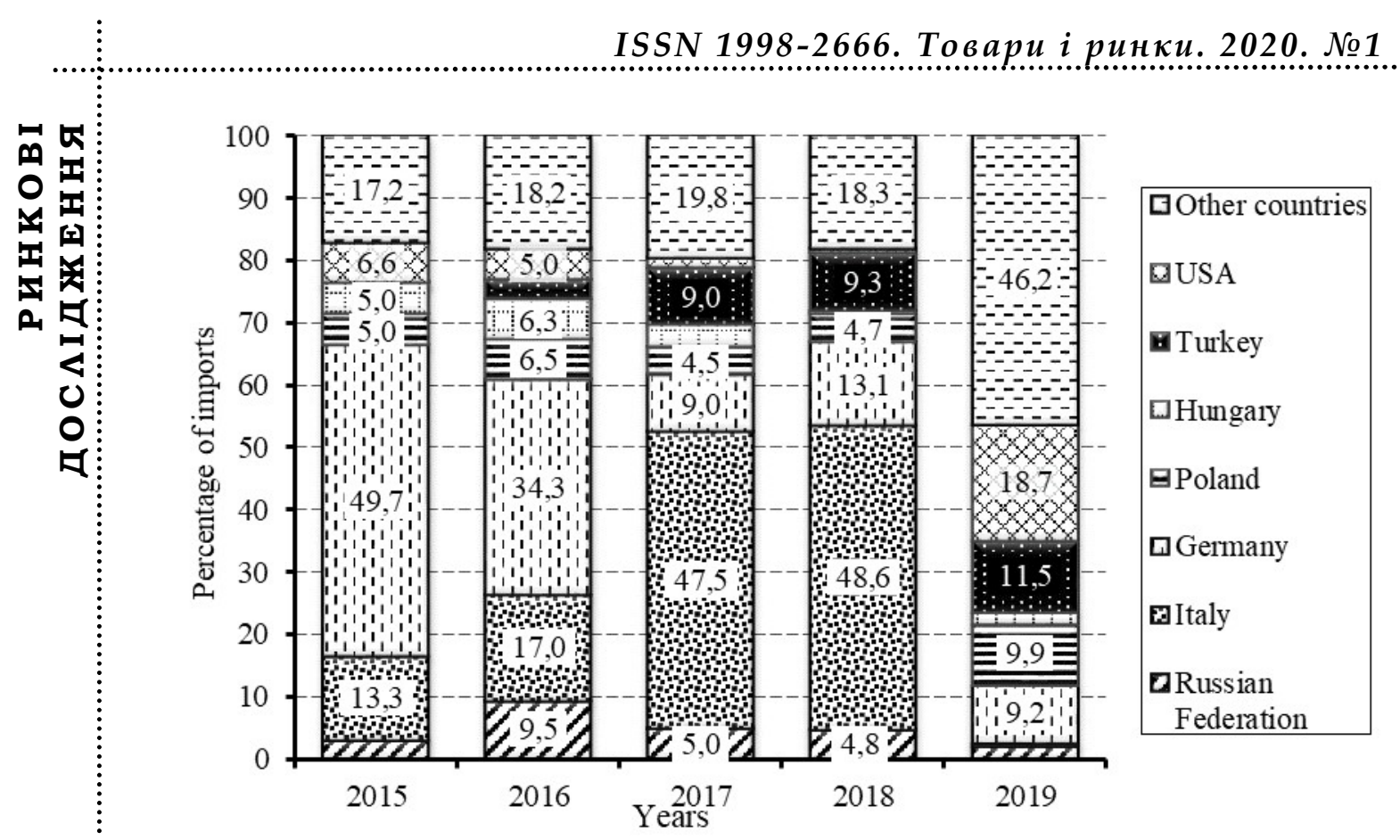

Fig. 5. Structure of import to Ukraine of cement DBMs (382450 UCG FEA) by leading countries-importers in 2011-2018.

Source: developed by the authors according to [13].

Cement DBMs compose an integral part of the construction industry of Ukraine. Their production is concentrated in large cities - regional and industrial centers of Ukraine (Kyiv, Kharkiv, Odessa, Dnipro, Lviv). This may be due to the fact that raw materials, production facilities, as well as developed infrastructure are available there. Given the complex development of economic districts of Ukraine, the geography of the industry must be constantly improved to fully provide increased volumes of construction works.

In the future, it is necessary to introduce effective integrated quality control at all stages of production and promotion of cement DBMs, which will strengthen the position of domestic manufacturers in the market.

Conclusion. Cement DBMs are quite widely used for construction of new buildings and reconstruction of old ones. In the period from 2015 to 2018 , cement DBMs production in Ukraine increased by $35.6 \%$, while the consumption of this product increased by $41.5 \%$. The leading domestic producers of cement-based SBS are Henkel Bautechnik LLC (Ukraine), Fomalgaut-POLYMIN LLC, Polirem LLC and Helios LLC.

The highest prices for cement DBMs in the period from 2016 to 2019 were on the mixture for flooring. They increased by $40 \%$ and prices for masonry mixtures - by $23 \%$.

Turkey and the US became the main importers to Ukraine of cement DBMs in 2019, with the part of $31 \%$ in the total import structure. Imports in 2019 outstripped exports by almost 8 times, which can be explained by the higher quality of cement DBMs of foreign production. 
1. Smachylo, V. V. (2016). Strategichni aspekty cinoutvorennja na rynku suhyh budivel'nyh sumishej v Ukrai'ni [Strategic aspects of pricing in the dry mix market in Ukraine]. Strategija ekonomichnogo rozvytku Ukrai'ny - The economic development strategy of Ukraine, 38, 51-64. Retrieved from http://irbisnbuv.gov.ua/cgi-bin/irbis_nbuv/cgiirbis_64.exe?C21COM=2\&I21DBN=UJRN $\& \mathrm{P} 21 \mathrm{DBN}=\mathrm{UJRN} \& \mathrm{I}$.MAGE FILE DOWNLOAD $=1 \&$ Image file name $=$ PDF $/$ seru 201638 7.pdf [in Ukrainian].

2. Boreyko, V. I. (2011). Perspektyvy vyrobnyctva budivel'nyh materialiv v Ukrai'ni [Prospects for the production of building materials in Ukraine]. Problemy racional'nogo vykorystannja social'no-ekonomichnogo ta pryrodno-resursnogo potencialu regionu: finansova polityka ta investycii' - Problems of rational use of the socio-economic and natural-resource potential of the region: financial policy and investments, 4, 64-71 [in Ukrainian].

3. Soha, Ju. I. Formuvannja budivel'nogo rynku Ukrai'ny [The formation of the construction market of Ukraine]. Retrieved from http://ena.lp.edu.ua/bitstream/ $\mathrm{ntb} / 2451 / 1 / 28$.pdf [in Ukrainian].

4. Pichugina, M. A. Analiz stanu rynku budivel'nyh materialiv Ukrai'ny [The analysis of the market situation of building materials in Ukraine]. Retrieved from http://spu.fmm.kpi.ua/article/view/73057/68388 [in Ukrainian].

5. Andreeva, T. Je. (2014). Optymal'ne vykorystannja syrovynnoi' bazy pidpryjemstvamy budivel'nogo kompleksu [The optimal use of the raw material base by the enterprises of the construction complex]. Budivel'ne vyrobnyctvo - Construction production, 57, 17-19 [in Ukrainian].

6. Biba, V. V. (2013). Stan ta perspektyvy rozvytku budivel'noi' galuzi Ukrai'ny [State and prospects of development of construction industry of Ukraine]. Galuzeve mashynobuduvannja, budivnyctvo - Industry engineering, construction, 4 (39). (Vol. 2), (pp. 3-9) [in Ukrainian].

7. Vyhrij, O. O. (2013). Osoblyvosti zastosuvannja suhyh budivel'nyh sumishej pry zvedenni ogorodzhujuchyh konstrukcij z gazobetonnyh blokiv avtoklavnogo tverdnennja [Features of application of dry building mixes for the erection of enclosure structures from aerated concrete blocks of autoclave hardening]. Budivel'ni materialy, vyroby ta sanitarna tehnika - Building materials, products and sanitary equipment, 47, 69-76 [in Ukrainian].

8. Zaharchenko, P. V. (2018). Innovacijnyj rozvytok rynku suhyh budivel'nyh sumishej v Ukrai'ni [The innovative development of dry mix market in Ukraine]. Visnyk LTEU. Tehnichni nauky - Herald of LUTE. Technical Sciences, 19, 23-29 [in Ukrainian].

9. Oficijnyj sajt Derzhavnoi' sluzhby statystyky Ukrai'ny [The official site of the State Statistics Service of Ukraine]. ukrstat.gov.ua. Retrieved from http://www.ukrstat.gov.ua [in Ukrainian].

10. Rynok suhyh budivel'nyh sumishej: stan ta prognozy (infografika) [The market of dry construction mixes: state and prospects (infographic)]. Retrieved from http://budport.com.ua/news/13193-rinok-suhih-budivelnih-sumishey-stan-taprognozi- infografika [in Ukrainian].

11. Rejestr cin na budivel'ni materialy za danymy Ministerstva regional'nogo rozvytku ta budivnyctva Ukrai'ny [Price list for building materials according to the Ministry of regional development and construction of Ukraine]. Retrieved from https://msmeta.com.ua/reestr_cin_na_budivelni_materiali.php [in Ukrainian]. 
12. Oficijnyj sajt Derzhavnoi' sluzhby statystyky Ukrai'ny. Krai'ny za tovarnoju strukturoju zovnishn'oi' torgivli [The official site of the State Statistics Service of Ukraine. Countries by commodity structure of foreign trade]. ukrstat.gov.ua. Retrieved from http://www.ukrstat.gov.ua [in Ukrainian].

13. Zovnishnja torgivlja okremymy vydamy tovariv za krai'namy svitu [Foreign trade in certain goods by countries of the world]. Retrieved from http://www.ukrstat.gov.ua [in Ukrainian].

Полюга В., Золотарьова О., Комаха О. Цементні сухі будівельні суміші в Украӥні: ринкові дослідження.

Постановка проблеми. Промисловість будівельних матеріалів містить у своєму складі виробництво цементу, цегли та інших стінових матеріалів тощо. Особливу зацікавленість викликає розвиток комплексу виробництва сухих будівельних сумішей.

Метою статmі є аналіз виробництва, споживання, імпорту та експорту цементних СБС в Україні протягом 2011-2019 рр.

Матеріали та методи. Під час проведення досліджень використано загальнонаукові та спеціальні методи аналізу та синтезу і порівняння джерел статистичної інформації за даними Державної служби статистики України та Державної фіскальної служби України.

Результати дослідження. У період з 2011 по 2015 рік відбувалося зменшення обсягів виробництва цементних СБС на $17.6 \%$. Основна частка припадає на виробництво СБС, в яких зв'язувальною речовиною є портландцемент (57 \%).

На сьогодні в Україні працюють майже 100 виробників цементних СБС, але 75-80 \% вітчизняного виробництва припадає на ТОВ "Хенкель Баутехнік (Україна)", ТОВ "Фомальгаут-ПОЛІМІН", ТОВ "Полірем" та ТОВ "Геліос".

Аналіз цін на ринку цементних СБС показав, що протягом останніх років відбувається підвищення цін на цементні СБС, незалежно від їхного виду.

У 2011-2018 рр. найбільші обсяги цементних СБС імпортувалися до України з Німеччини, РФ, Франції та Китаю.

Висновки. Моніторинг цін на цементні СБС показав, що протягом 20162019 pp. найвищі ціни мали цементні суміші для влаштування підлог, які зросли за три роки на $40 \%$.

Основними країнами - імпортерами цементних СБС у 2018 році були Німеччина, Російська Федерація та Китай. Імпорт у 2018 р. переважав над експортом у 16 разів, що можна пояснити вищою якістю цементних СБС закордонного виробництва проти вітчизняних.

Ключові слова: цементні сухі будівельні суміші, стан виробництва, імпорт, експорт, ринок. 